\title{
Studying Sport in the University: Some Problematics and Problems
}

\section{Lucia Trimbur}

In an interview with the Los Angeles Review of Books in November 2014, Lisa Duggan, then president of the American Studies Association (ASA), was asked about the state of the field. When her interviewer suggested that American studies is "a department for boys who wanted to write about baseball," Duggan responded, "Well, we still have that!" She continued,

I'm laughing, but that does describe a part of the field. But, if you look through the conference program, you see ... work in black studies, ethnic studies, histories and politics of sexuality, in addition to more overtly political work on settler colonialism or on US relations with other parts of the world. ${ }^{1}$

Duggan's first response to her interviewer's description - so silly that it provoked laughter - upholds sport studies as juvenile and homosocial. Her observation that "we still have that" intimates that sport studies clings on, despite irrelevance. Contrasting sport studies with many of American studies' most important and thriving areas of inquiry, Duggan implies that black studies, ethnic studies, gender and queer theory, and settler colonialism demand serious intellectual research while sport studies merits a chuckle. Both comments-what sport studies is and what it is not—stem from deeply rooted work/play dichotomies and mental/manual distinctions: How can talk of bodies at play beget rig- 
orous study? Both comments also assume that sport studies is so hermetically sealed that it cannot include women or be concerned with the notable topics that command the intellectual and political engagement of the rest of American studies.

Such characterizations of sport studies may be outdated, but the concomitant dismissal of the subfield is not. Just five months before the interview, the Journal of American History $(\mathrm{JAH})$ published an issue dedicated to the state of sport history and sport studies more generally. ${ }^{2}$ In the opening essay, Amy Bass laments, "I propose that writing about sports from a historical perspective is entangled in a mess of somewhat unique complications. ... [the] first problem lies in a general lack of respect for the field of sports history - what one scholar recently described as 'the snubbing of sport history by mainstream historians."'” Though the source of this disrespect and the form of these snubs are largely left unspecified, many of the volume's authors concur with Bass's assessment: Excellent scholarship is produced in the subfield, but it remains sidelined. Despite progress, such as the formation of the vibrant Sports Studies Caucus of the ASA, researchers in sport studies struggle for legitimacy.

To read Duggan, Bass, and the prominent $J A H$ contributors, it would not be unreasonable to think there is a real crisis of legitimacy in sport studies. And yet, the quality of the literature, the number of books reviewed in prominent generalist journals, the spaces for intellectual collaboration, and the opportunities for debate are inversely proportional to the contention of marginalization. How, then, can we understand these apparently contradictory positions?

Historically, academics have been ambivalent about studying popular cultures and "low-brow" social practices and historical processes. The Centre for Contemporary Cultural Studies scandalized literary theorists and historians alike with their careful analyses of lived cultures. Stuart Hall remembers that cultural studies' methods "triggered off a blistering attack from sociology," while the Centre's later focus on sexism and patriarchal domination, race and racism, and militarism only enlarged the choir of disbelievers, who dismissed meticulous research as merely "political." But today's anxiety about sport studies represents more than ambivalence. At a moment when nearly 20 million people tune into the National Football League's (NFL's) opening week, ${ }^{4}$ when 1,000 college athletes earn upwards of $\$ 900$ million in profits for the National Collegiate Athletic Association (NCAA) during March Madness, ${ }^{5}$ and when college coaches can expect millions of dollars in base salary, ${ }^{6}$ sport studies has never been more relevant.

This essay suggests that anxiety about sport as an academic object of inquiry emerges from the fact that sport studies lacks neat assimilation into dominant social divisions of knowledge. Sport studies draws on diverse methods, theoretical frameworks, and epistemological formations for concrete study; this is its strength, not its weakness. The refusal of sport studies to codify itself produces an openness that allows intervention in places that are unsuspected. The absence of adjudication within the subfield prevents both boundaries and 
monopolies. Put differently, critical nimbleness is a source of sport studies' intellectual power.

What follows is an analysis of some of the ways scholars theorize sport and use it to see and perceive the world in order to illuminate how the subfield generates detailed conjunctural analyses. ${ }^{7}$ My motivation is not proprietary-as referenced above, sport studies has benefited from a lack of arbitration-but rather to provide a snapshot of books published since 2010, when the seeds of the Sports Studies Caucus began to germinate. I have organized these snapshots into problematics within American studies to demonstrate how interventions in sport studies connect with some of American studies' core axes. ${ }^{8}$ Analytically, I draw on the idea of intervention rather than definition; with a disinterest in demarcation but determination to inhabit a specific scholarly space, current work in the subfield intervenes while being attentive to changing forces, tendencies, and relations of power. ${ }^{9}$ Intervention prevents sport studies' merely responding to hegemony on its terms by creating and using the subfield's own terms. Finally, intervention is forward looking: it encourages scholars to contemplate how we might advance based on the current conjuncture and to articulate possibilities for progressive futures.

\section{Problematics}

From Johan Huizinga to Roger Caillois to Allen Guttman, writers interested in play have tried to theorize the elusive concept and to explain just what those who engage in sporting activities can hope to experience. ${ }^{10}$ In the literature, definitions and functions of sport are as varied as the physical forms they take. For some, sport reflects social circumstance, ${ }^{11}$ for others it is an expression of collective identity. ${ }^{12}$ Some researchers suggest that sport is a site for the reproduction and contestation of identities - gender, racial, ethnic, sexual, ability ${ }^{13}$ — while others still see the sporting body as a resource for building new ideologies, both radical and reactionary. ${ }^{14}$ Regardless of perspective, sport has proved to be integral to many of American studies' key areas.

\section{Critical and Literary Theory}

In Ball Don't Lie!: Myth, Genealogy, and Invention in the Cultures of Basketball (2016), Yago Colás deploys stories, metaphors, and images - what he calls "myths" - to analyze how truths are produced, authority conferred, and power challenged on and off the court. ${ }^{15}$ In three parts-Myths of the Basketball Republic (1881-1949), Myths of the Modern Basketball State (1949-1991), and Myths of the Basketball Empire (1991-Present) - Colás disrupts basketball commonsense about concepts as small as technical fouls and as large as modernism to reveal deeper political, social, and cultural meanings. Careful close readings of narrative propositions coupled with rigorous sociological and historical research allow Colás to explicate both the antiblack racism embedded in naturalized ideas about the young black men who compose the majority of 
basketball's practitioners as well as the creative ways players have innovated and subverted authority and stereotypes. Ball Don't Lie! denaturalizes assumptions in sport and society about hierarchies of power and about the roles and responsibilities of black athletes. Colás, ultimately, offers alternative ways to read basketball mythology, problematizes reductive constructions of blackness, and proposes autonomist/horizontalist possibilities.

In Motion, At Rest: The Event of the Athletic Body (2014) by Grant Farred takes as its object of study three sporting figures: Ron Artest, Eric Cantona, and Zinedine Zidane. To Farred, these athletes represent events, disruptions that break the routine of the everyday, generating understandings previously inaccessible. Drawing on Alain Badiou, Farred argues, "The event is that precise and unexpected instant that we did not — could not—see coming; the event transforms entirely a humdrum, or even a crucial encounter into a historic occurrence."16 In Motion, At Rest contextualizes the event to identify the ripple effects it has in the social world. Rather than see the event as an interruption, Farred imagines it as a priori, always part of sport's repertoire, but not completely knowable until the moment of its expression and afterward.

In the first chapter, for example, Farred analyzes the last minutes of the 2004 Pacers-Pistons game in which Ron Artest was charged with a flagrant foul (on Ben Wallace), tussled with other players, retreated to rest on the scorer's table before being assaulted by Detroit fans and catapulting into the stands. At this moment, the event of Artest opens up: to other social and historical forces as well as to itself. By retreating to stillness on the scorer's table, a number of other possibilities were set into motion; Artest's decision to engage a supine state (his subtraction from athletic activity) serves two functions. First, the black body asserts itself at rest, of its own choosing, and draws attention to itself thereby disordering all around it. Second, the black body at rest connects itself to other self-immobilized black bodies in history. Farred writes,

The black body at rest can never be at rest only by itself; the black body at rest draws other black bodies at rest toward it, draws these historic bodies into the situation, other bodies that are, on the face of it, totally disconnected from the event at hand-the event that is not discrete because of the ways in which the multiple resonates. ${ }^{17}$

Farred links the event of Artest to the political convictions and decisions of Rosa Parks, John Carlos and Tommy Smith, and Muhammad Ali, among others. Artest's chosen stillness withdraws his labor, which is "unthinkingly expected of the NBA athlete" as well as gathers Artest with other black people in history. The event of Artest is then dependent on events over time and a uniquely African American experience. The event also provides resources for new forms of thought and communication. 


\section{Critical Prison Studies}

After Artest: The NBA and the Assault on Blackness (2012) by David J. Leonard also analyzes the "Palace Brawl" and how the November 2004 incident radically changed the National Basketball Association's (NBA) approach to race and racism. ${ }^{18}$ For Leonard, the evening's events generated a moral panic among league officials about the image of the NBA and ushered in a wave of policies designed to curb the "urban" styles and expressions-real and imagined-that black players self-fashioned. Through regulatory practices such as dress codes and age requirements, Commissioner David Stern sought to reconfigure the league's racial signifiers after the illusion of racial transcendence and color-blindness had been shattered. What Stern accomplished in practice was to alter the racial landscape of the NBA by casting blackness as danger and framing players as in need of paternal supervision.

Careful not to isolate sport from other social institutions, Leonard connects struggles over racial meanings in professional basketball with similar narratives in criminal justice and education. He writes, "[A]s basketball is more than a game, the policies, representations, and narratives articulated through and about the NBA (and its black players) have a larger place, meaning, and significance in our society." 19 Of particular strength is Leonard's attention to the criminalization of blackness and relations of domination and subordination in both sport and society. In conversation with critical prison studies, he elucidates how regulations in the NBA not only mirror criminal justice polices but also work to reinforce them and reify ideas about black criminality.

\section{Gender and Sexuality Studies}

At forty-three, Erica Rand bought a pair of figure skates to mix up her workout routine, and after one swirl on the ice she never looked back. Red Nails, Black Skates: Gender, Cash, and Pleasure On and Off the Ice (2012) chronicles Rand's adventures in the world of adult figure skating and analyzes the larger sport of professional figure skating. Based on participant observation, which includes trips to the Gay Games and Adult Nationals, formal interviews with participants, informal conversations among friends, and media analysis, Rand looks at the sport's patterns of inclusion and exclusion, asking how inequality connects with the pleasures of ice skating. Writing from a position of queer femme, Rand contextualizes both commonsensical and surprising preconditions of joy in the sport despite gender rigidity, class differences, racial assumptions, and heteronormativity. Her work also searches for sites of rupture and places where skaters can cultivate their own expressions of identity.

Of note in Red Nails, Black Skates is Rand's unwillingness to universally condemn or naively admire the sport in which she is immersed. Rather, she seeks to understand the relations of power in skating, the delight practitioners derive from the rink, and the connections with society at large. She proposes, "Sports pleasures, like other pleasures, never float free. To the contrary, as nu- 
merous critics have emphasized, many pleasures, along with the very concept of leisure time itself, owe much of their development and characteristics to those who benefit from the inequities in current regimes of power. ${ }^{{ }^{20}}$ This position allows Rand to struggle with the sport's politics of pleasure while drafting an important list of changes to the skating world that could increase access to and fairness on and off the ice.

R. Tyson's Smith's elegant ethnography Fighting For Recognition: Identity, Masculinity, and the Act of Violence in Professional Wrestling (2014) follows the quest of white working-class men on Long Island to develop new subjectivities. Based upon years of participant observation research and rigorous interviewing, Smith delves into the world of independent wrestling, asking why men participate in a sport universally denigrated and often a source of stigma and ridicule. Smith compellingly argues that wrestling enables some blue-collar white men to build trust with each other, to develop a desperately needed community, and to achieve recognition from fans and other wrestlers. He demonstrates the complicated way men cope with changing social circumstances, such as deindustrialization, using the resources available - both progressive and reactionary, such as homoeroticism and homophobia. Though his ethnography focuses on wrestling, his text explicates how dominant forms of Western masculinity - as currently defined and enacted - are harmful both within and without sport and how patriarchy and heterosexism not only injures women, girls, and boys, but also men. Fighting for Recognition is an effort to challenge and reimagine the boundaries of masculinity and sexuality. ${ }^{21}$

\section{History of Capitalism and Labor Studies}

In a brilliant reconsideration of Norbert Elias's civilizing process and attendant concept of sportization, Tony Collins forgoes figurative analyses, writing instead a materialist history of modern sport in Sport in Capitalist Society: A Short History (2013). By looking at how sport was molded by the printing press, advances in communication and travel, imperialist adventures, and the development of a larger entertainment industry, Collins maintains that sport has not been perverted by capitalism over time but is a constitutive feature of it. Like factories, trading floors, and bread lines, sport in Britain, Europe, North America, and Japan became an institution of great commercial importance in twentieth-century life. Collins contends that features of modern sport, such as the commitment to rules, regulations, and transparency are not rational products of Weberian progress but rather preconditions of commercialization. Rules, for example, were derived from the need for sport to be predictable so that markets could be created and capital extracted. Collins asserts,

Sport was not merely coterminous with the expansion of capitalism but an integral part of that expansion, not only in economic organization but also in ideological meaning. At the level of everyday discourse and seemingly empirical 'com- 
mon sense' — what might be termed deep politics — modern sport was capitalism at play. ${ }^{22}$

Sport was never the domain of its practitioners but has always been a profitdriven venture. He continues, "The idea that sport has been hijacked by team owners or commodified by corporate interests fails to understand that modern sport is itself a creation of capitalism."23

Daniel A. Gilbert's Expanding the Strike Zone: Baseball in the Age of Free Agency (2013) examines collective struggles for and around free agency and the unionization of baseball players. In the mid-1960s, ballplayers, recognizing that they were radically undercompensated considering profit margins, resuscitated the Major League Baseball Players Association (MLBPA). The MLBPA became one of the most successful labor institutions in the United States and helped revise both the practices of free agency and the meanings of workers in their industry. Gilbert argues that this was accomplished, in large part, by athletes' public illustration of their indispensability; because of their high visibility - baseball players are among the most well-known American workers - and their contract fights became some of the most prominent. He suggests, "The MLBPA's stunning success from the 1960s onward depended on the union's successful mobilization of star power. The players built their union by asserting control over their own commodification ... and proved that Major League Baseball could not exist without their own popular appeal."24 And yet almost as quickly as athletes were able to win collective bargaining agreements, team owners developed less overt forms of control over the labor power of the sport's least-protected players. Gilbert deftly shows how more concessions won for MLB players led team owners and officials increasingly to pursue flexible labor from leagues and academies in Latin America.

Gilbert's book demonstrates that, like most modern sport, baseball has always been transnational, even when nostalgically considered the United States' national pastime. It also highlights the connections among work, workplaces, and the quest for freedom from capitalism, between the social and economic conditions that create the need for escape and forms of mass-produced culture. Importantly, Expanding the Strike Zone shows how sport moved to flexible forms of global production so wealth could consolidate in the hands of a privileged few. With its focus on flexible accumulation and flexible citizenship, Expanding the Strike Zone reveals that sport is always inseparable from larger relations of forces and is a robust site for critically engaging neoliberal globalization.

\section{Performance and Visual Studies}

Shaped by similarities among his own experiences, his reading of Fanon's experiences, and the objectification of racial difference over centuries, Harvey Young masterfully analyzes how the black body has been constructed and projected onto the lived experience of people seen as racial Other. In Embodying Black Experience: Stillness, Critical Memory, and the Black Body (2010), 
Young shows how misrecognition across time can produce shared experiences of unjust incarceration and violence. He illuminates how the move from abstraction to materiality generates myriad forms of racial abuse and confinement and argues, "Beyond drawing attention to the continuing existence or legacy of racial assumptions, I contend that their projections across individuated bodies exist as acts of violence that assume a variety of forms: an epithet, racial profiling, incarceration or captivity, and physical/sexual assault." Organized by genre - photography, sport, theater, and museum display-Embodying Black Experience takes as its overarching focus what Young calls "the mystery of blackness," an idea that becomes fact through its repetition in the material world. ${ }^{25}$

Young's intervention is critical memory, or the consideration, articulation, and sharing of collective instantiations of black experience as resistance to individual episodes of racial abuse. Chapter 3, for example, explores four generations of black boxers-Tom Molineaux, Jack Johnson, Joe Louis, and Muhammad Ali - to understand how subjectivities were formed both by societal projections of blackness as well as the boxers' own critical memories. Young suggests that all boxers had control over the "presentation and re-presentation of their own bodies" and looked to men before them when making decisions. When a boxer such as Muhammad Ali refused induction into the army during the Vietnam War, for instance, he had in mind the travails of other black boxers in history ${ }^{26}$ Young suggests, "Each had a similar relation to captivity, having lived in or under the threat of captivity. Each knew that his body represented more than the physical limits of his own body. Each, as time progressed, learned the experiences of those who preceded him and made life decisions aware of the fate of the others. All of the boxers within this study were ghosted by the institution of black captivity and/or the threat of incarceration." ${ }^{27}$ By linking representations of seemingly disparate people across time - black artists, athletes, and performers-Young makes a powerful case for integrating analyses of sport into historical and cultural studies, broadly defined, in order to better comprehend dynamics of racial terror and their refusal, past and present.

\section{Slavery and Abolition Studies}

Katherine C. Mooney showcases the best of sport studies through a superb analysis of what horse racing offered both slave owners and the captive men who performed the majority of the sport's labor. In Race Horse Men: How Slavery and Freedom Were Made at the Racetrack (2014), Mooney argues that horse racing went beyond a popular pastime to constitute a vital social institution that offered wealthy white men opportunities for identity formation, hierarchical social relations, and justifications for the right to rule. She explicates, "Eighteenth-century racing enthusiasts coined the name 'turfmen' for themselves, adopting it as a title of rightful authority both on and off the track. To be a turfman was not merely to be rich; it was to be a gentleman worthy of respect in the most select circles for savvy judgment, grace and style. ${ }^{28}$ The racetrack 
was an elite and elitist site, one that thrived on the most severe forms of division and inequality.

For the black men who trained, cared for, and rode racehorses, the sport provided a modicum of maneuvering room in captivity: horse racing was a sphere in which black men could speak and command respect. Because their skills and expertise were needed by the white men who forcibly took them as property, black men who worked with race horses could expect a bit more mobility, autonomy, and opportunity than other slaves. Mooney contends, "Slaves were prominent in racing crowds because including them also bolstered the existing order. Masters used race days to demonstrate that their power was rightful or at least inevitable." ${ }^{29}$ Mooney shows that though white plantation owners invested in black men's expertise and permitted certain conscribed privileges, white turfmen used those same privileges to justify human bondage, "creat[ing] a form of slavery all the more powerful and resilient because it allowed for and fed on the extraordinary accomplishments of black horsemen rather than seeking to suppress them." ${ }^{30}$

\section{Transnational and Diasporic Studies}

Ben Carrington's Race, Sport and Politics: The Sporting Black Diaspora (2010) chronicles the invention of the "first black athlete" and the signifying systems developed through this new figure. Interested in both the burden the black athlete was asked to bear historically and continues to carry in modern sport today, Carrington argues that the very idea of the black athlete, as the brainchild of European colonial racism, quickly became the symbol through which fantasies about blackness were constructed. With little opportunity to speak, the black athlete has been spoken for by others and defined instead "by common folklore, sports discourse-most powerfully within the sports media - and by the advertising industries, by pseudo-scientific inquiries and the educational system, and by athletes themselves, fans, sports administrators and officials. ${ }^{" 31}$ Modern sport-with its rule-dominated, meritocratic, and patriarchal promises - was a precondition for the black athlete and continues as the site of never-ending struggles over the meanings of racial difference.

Carrington uses the idea of the sporting black Atlantic to render visible the lived experiences, movements, and meanings of black athletes over the past 200 years and to elucidate the ways in which modern sport is a constitutive part the black diaspora. The sporting black Atlantic allows Carrington to demonstrate the role black athletes played and continue to play in Europe, North America, the Caribbean, and throughout the African diaspora in creating forms of racial and interracial solidarity, utopian possibilities, novel visions of freedom, and demands for recognition.

In Jack Johnson, Rebel Sojourner: Boxing in the Shadow of the Global Color Line (2012), Theresa Runstedtler analyzes boxer Jack Johnson's public fights - literal and metaphorical-against antiblack racism to pen a stunning global history of twentieth-century race, gender, and empire. Runstedtler 
challenges popular representations of Johnson's accomplishments, conflicts, and significance that operate solely within the national borders of Jim Crow America, arguing that confining Johnson to the United States attempts to extinguish his memory and legacy. By following Jack Johnson and the controversies that confronted him to Cape Town, Havana, London, Mexico City, Paris, and Sydney, Runstedtler contends, "Johnson was part of a hardscrabble world of black men who traveled extensively as professional fighters, minstrel performers, circus attractions, maritime workers, casual laborers, and sometimes all of the above." 32 Through their daring, achievements, travels, and prominence, Johnson and a cadre of black boxers formed a black counterculture that shook the foundations of white supremacy. Along with the work of black Atlantic intellectuals and advocates, Johnson helped spark what Runstedtler calls a "popular black global imagination" that affected ordinary black people in the United States and beyond. ${ }^{33}$

Jack Johnson, Rebel Sojourner connects ideas about racial difference with the rise of global capitalism:

The color line they faced was not a relic of days gone by, nor was it just a simple matter of individual or national psychology. Although built on the racial regimes of an earlier era of slavery and empire, it was a quintessentially modern construction. While definitely shaped by local, national, and regional conditions, it was also a global structure routed in the transnational flow of capitalist imperialism, urban industrialism, and the expanding mass culture industries. ${ }^{34}$

Runstedtler then links Johnson's battles against the color line with the contemporary and argues that the heavyweight's racial politics can shed important light on current discussions about race. Her text, then, is a history of the present: not content to leave Johnson's life in the past, she connects Johnson's with the complexities of antiblack racism in the Age of Obama.

To explore how citizenship is formed in diasporic circumstances, Stanley I. Thangaraj looks at a woefully underresearched area: South Asian athletes participating in mainstream US sport. Desi Hoop Dreams: Pickup Basketball and the Making of Asian American Masculinity (2015) maintains that while substantial research has been conducted on the near-mythic participation of South Asian men in cricket, less attention has been paid to the sporting pursuits of men who play basketball, baseball, football, and hockey. Set against dominant essentializing constructs of Asian American masculinity as "nerdy" or "possibly terroristic" and always "foreign," Thangaraj sets out to understand how men use basketball for homosocial bonding, to negotiate identity, and to see themselves in new ways. He compellingly suggests that participating in this sporting culture allows Asian American men to express love for and find belonging in basketball specifically and American popular culture more generally. 
Through over three years of formal ethnographic research in South Asianonly pickup basketball, Thangaraj shows how the conditions for belonging can be ethnically bounded spaces; as a heterosexual, middle-class, and ethnically exclusive enterprise, Asian American basketball leagues often exclude black players as well as desi women and gay South Asians. Desi Hoop Dreams demonstrates the complicated configurations of masculinity, race, ethnicity, class, and sexuality. As Thangaraj claims, "Within South Asian-only venues, players inscribe meanings to their brown bodies that are not available in other realms of society. At the same time, the limits of these meanings provide useful information about other types of exclusions present in masculinity formations. ${ }^{35}$

\section{The Future of Sport Studies}

The full-length books reviewed above - an exciting yet intentionally small sample of books produced in the past six years alone - illuminate how sport can offer a critical lens through which to understand larger social practices, social relations, social structures, and relations of power. As both an embodied and discursive site with vast potential for uncovering veiled aspects of domination and subordination, sport studies can both denaturalize commonsensical ideas and constitute a crucial site of knowledge production. ${ }^{36}$

Through their close readings, Colás and Farred uncover alternative meaning-making systems and elucidate greater social, cultural, and political tendencies untapped in much historical work. Carrington, Runstedtler, and Thangaraj's texts illustrate how black and brown athletes in diasporic spaces use sport and have been used in sporting circumstances to construct ideas about racial difference, gender, class, and nation. These authors powerfully present how athletes have been constitutive in projects that discursively and materially construct "race." All authors show how athletes resist these constructions, asserting their own visions of solidarity, belonging, and liberation, sometimes consciously and sometimes not.

As these texts show, sport studies often does do the work of the "overtly political" referenced in the first paragraph of this essay. The authors reviewed seek better understandings of what Richard Johnson calls "differences that make a difference" in sport, but they are not, by any means, content to merely interpret the world. The project of intervention is translation into the real world. And here revisiting the discussion of play in the LA Review of Books is important. As almost every scholar of American studies knows, how we talk reveals deep-seated structures of understanding; we can acknowledge the limits of off-the-cuff jokes while seeing their content as a larger symptom. In this case, banter about play recapitulates work/play and mental/manual dichotomies that shape how American studies thinks about sport. So, the argument goes, sport is a hobby and the amateur is in love with the subject, so her or his labor cannot be serious discerning work. And yet, for most sport studies scholars, play tells us a lot about what constitutes work, and when we talk about play, we are ask- 
ing - implicitly or explicitly_hard questions about labor as well as pleasure and joy. Sport studies troubles deeply ingrained dichotomies while analyzing some of the most pressing racial, labor, and gender conflicts that today are being fought on and off the playing field. Similarly, some of sport studies' most useful contributions are politically connecting these struggles with larger theories of neoliberalism, patriarchy, racism, senescent capitalism, as well as liberation, in order to fight for a different kind of society.

And yet a lack of concreteness can make our subfield feel, at times, discombobulated. Sport studies' same committed pursuit of meaning against reductive labels and boundaries may be misunderstood as a kind of laziness or fuzziness. The multiplicity of places the subfield intervenes and the attendant requirement of being legible in numerous contexts that are structured in different ways can be confusing. But those misunderstandings and particular demands of interdisciplinary work do not determine either the subfield's legitimacy or worth. Furthermore, whenever a subfield experiences a surge, there are uneven developments; disagreement can be particularly pronounced in a moment of great transition.

And sport studies is in precisely that moment. In two years, the subfield has warranted special editions in notable journals such as the Journal of American History and the American Studies Journal, as well as produced numerous panels on sport at the ASA sponsored by the Sports Studies Caucus, submitted independently, and jointly sponsored with other caucuses, such as the Critical Prison Studies Caucus. The subfield is enjoying the airtime it deserves, and my hope is that this issue inspires more connections and provides more opportunities for discussion and debate. Sport studies has room for a range of views, perspectives, methods, and objects of study. Let this be a jumping off point for more journal issues proposing more links between sport and the social world. For as Stuart Hall reminds us, "intellectual work does not consist only of what has been studied, of the theories and methods employed or even of the provisional results obtained. It also has to do with the practice itself-with how it is performed." ${ }^{37}$ Sport studies is open to forms of practice and performance-new and old - that promise rigorous engagement.

\section{Notes}

I thank Noah Cohan, Yago Colás, and the anonymous reviewers of this paper for their helpful comments. I thank Paul Gilroy for showing me the multiplicity of ways one can approach the study of sport.

1. Sarah Mesle, "Sarah Mesle Interviews Lisa Duggan: Fun, Fury, and the American Studies Association," Los Angeles Review of Books, November 6, 2014, https://lareviewofbooks.org/ interview/fun-fury-american-studies-association

2. The issue conflates sport history with sport studies.

3. Amy Bass, "State of the Field: Sports History and the "Cultural Turn,", The Journal of American History 101, no. 1 (2014): 149.

4. Rick Kisdell, Ratings: NFL Draws Record Audience for Opening Week, http://variety. com/2015/tv/news/nfl-record-ratings-for-opening-week-1201595991. 
5. Jonathan Berr, MONEYWATCH, March 20, 2015, http://www.cbsnews.com/news/marchmadness-follow-the-money. coach.

6. NCAA Salaries, USA Today, http://sports.usatoday.com/ncaa/salaries/mens-basketball/

7. This review focuses on recent books largely because American Studies is a book-focused discipline but also because articles require more space than that provided here. This is not to suggest that books are inherently more substantial or rigorous than articles; to the contrary, there a number of critical articles that have greatly influenced the subfield.

8. Similarly, there are a number of ways to organize and order the following studies; simply because a text appears in one problematic does not mean it is not also part of another. I organized books according to the primary problematic in which I believe the text is intervening. But authors will recognize cross-fertilization. Again, for practical reasons I have not included articles or edited volumes. Furthermore, some readers will notice I do not mention my own work; I find it awkward in such a setting to write about my book, but I hope that it is considered allied with the projects of the authors I review.

9. I draw from Stuart Hall's classic essay in which he recounts the Centre's determination not to delineate the range or scope of its scholarly practice, choosing instead interventions that could occupy a particular space. Intervention both illuminates objects of study and by virtue of its mixed approaches also brings to light areas that have not received attention. Stuart Hall, "Cultural Studies and the Centre: Some Problematics and Problems," in Culture, Media, Language: Working Papers in Cultural Studies, 1972-79, eds. Stuart Hall, Dorothy Hobson, Andrew Lowe, and Paul Willis (London: Routledge, 1980), 15-47.

10. To my mind, the avant-garde writer and cofounder of France's College de Sociologie pour l'Etude du Sacre, Roger Caillois, is the most elegant theorizer of sport. In his treatise Man, Play and Games, Caillois sets out to understand the concept of play. While indebted to the thinking of Johan Huizinga but dissatisfied with the limits of Huizinga's analyses, Caillois contends that play is a practice that is free/voluntary, circumscribed in time and space, uncertain, unproductive, governed by rules, and make-believe. Play is also a waste - of time and energy - in which nothing is produced. And though it has no intrinsic meaning, play is attractive to practitioners for the possibilities and transformations offered in the moment of execution. Play creates an escape from the pressures of everyday life and temporarily allows people to become other kinds of beings. Games, the domain of play, have four features: competition (agon), chance (alea), simulation (mimicry), and vertigo (ilinx). These features take different configurations in the social world as social relations and social practices change. See Roger Caillois, Man, Play and Games (Urbana: University of Illinois Press, 2001).

11. See, for example, Elliott Gorn, The Manly Art: Bare-Knuckle Fighting in America (Ithaca: Cornell University Press, 2010); James Walvin, Football and the Decline of Britain (New York: Palgrave, 1986).

12. See, for example, Lawrence W. Levine, "The Hero vs. Society: John Henry to Joe Louis," in Black Culture and Black Consciousness: Afro-American Folk Thought from Slavery to Freedom (New York: Oxford University Press, 2007); Gerald Early, The Culture of Bruising: Essays on Prizefighting, Literature, and Modern American Culture (Hopewell, NJ: Ecco Press, 1995); Clifford Putney, Muscular Christianity: Manhood and Sports in Protestant American 1880-1920 (Cambridge: Harvard University Press, 2003); Michael Berkowitz, Zionist Culture and West European Jewry Before the First World War (Chapel Hill: The University of North Carolina Press, 1996); Susan Brownell, Training the Body for China: Sports in the Moral Order of the People's Republic (Chicago: University of Chicago Press, 1995).

13. See, for example, Gail Bederman, Manliness and Civilization: A Cultural History of Gender and Race in the United States, 1880-1917 ( Chicago: University of Chicago Press, 1996); Mark Stimpson, Male Impersonators: Men Performing Masculinity (New York: Routledge, 1994); Jennifer Hargreaves, Sporting Females: Critical Issues in the History and Sociology of Sports (New York: Routledge, 1994); John Hoberman's Darwin's Athletes: How Sport Has Damaged Black America and Preserved the Myth of Race (Boston: Mariner Books, 1997).

14. See, for example, Karl Toepfer, Empire of Ecstasy: Nudity and Movement in German Body Culture 1910-1935 (Berkeley: University of California Press, 1997); Michael Anton Budd, Sculpture Machine: Physical Culture and Bodily Politics in the Age of Empire (New York: New York University Press, 1997); and especially Garry Robson, "No One Likes Us, We Don't Care:" The Myth and Reality of Millwall Fandom (London: Bloomsbury Academic, 2000).

15. Yago Colás, Ball Don't Lie!: Myth, Genealogy, and Invention in the Cultures of Basketball (Philadelphia: Temple University Press, 2016).

16. Grant Farred, In Motion: At Rest: The Event of the Athletic Body (Minneapolis: University of Minnesota Press, 2014), 1.

17. Ibid., 27.

18. David Leonard, After Artest: The NBA and the Assault on Blackness (Albany: State University of New York Press, 2012).

19. Ibid., 21. 


\section{Lucia Trimbur}

20. Erica Rand, Red Nails, Black Skates: Gender, Cash, and Pleasure On and Off the Ice (Durham, NC: Duke University Press, 2012), 238.

21. R. Tyson Smith, Fighting for Recognition: Identity, Masculinity, and the Act of Violence in Professional Wrestling (Durham, NC: Duke University Press, 2014).

13

22. Tony Collins, Sport in Capitalist Society: A Short History (New York: Routledge, 2013),

23. Ibid., 127.

24. Daniel A. Gilbert, Expanding the Strike Zone: Baseball in the Age of Free Agency (Boston: University of Massachusetts Press, 2013).

25. Harvey Young, Embodying Black Experience: Stillness, Critical Memory, and the Black

Body (Ann Arbor: University of Michigan Press, 2010), 6.

26. Ibid., 112.

27. Ibid, 114.

28. Katherine C. Mooney, Race Horse Men: How Slavery and Freedom Were Made at the Racetrack (Cambridge, Harvard University Press, 2014), 5.

29. Ibid., 37.

30. Ibid., 48.

31. Ben Carrington, Race, Sport and Politics: The Sporting Black Diaspora (Washington, DC: Sage, 2010), 2.

32. Theresa Runstedtler, Jack Johnson, Rebel Sojourner: Boxing in the Shadow of the Global Color Line (Berkeley: University of California Press, 2012), 5.

33. Ibid., 7.

34. Ibid., 5 .

35. Stanley I Thangaraj, Desi Hoop Dreams: Pickup Basketball and the Making of Asian American Masculinity (New York: New York University, 2015), 5.

36. This analysis of sport studies also reveals the extent to which American Studies, as an association, is composed of subfields. And it would certainly be worth thinking more deeply about how subfields structure American studies, how they themselves are disciplining, and whether or not they are the best way to organize knowledge. There is not enough space here. But suffice it to say that ignoring subfields or dismissing them outright denies the fact that people have self-organized and that it is helpful for scholars to identify others interested in similar topics. Dissolving sport studies into American studies as a theme risks losing these connections as well as opportunities to systematically and jointly ask questions about how connections work. I suppose what I am arguing is that to see sport studies merely as a theme is to dissolve a self-organized attempt that has already happened. I do not see sport studies as further specialization but rather as a recognition that one can best study sport through its links with other subfields.

37. Ibid., 43. 